\title{
SOME ALCYONIID OCTOCORALS FROM KII COAST, MIDDLE JAPAN
}

\author{
$\operatorname{AUTHOR}(S):$
}

Utinomi, Huzio

\section{CITATION:}

Utinomi, Huzio. SOME ALCYONIID OCTOCORALS FROM KII COAST, MIDDLE JAPAN. PUBLICATIONS OF THE SETO MARINE BIOLOGICAL LABORATORY 1954, 4(1): 43-55

\section{ISSUE DATE:}

1954-11-20

URL:

http://hdl.handle.net/2433/174502

RIGHT: 


\title{
SOME ALCYONIID OCTOCORALS FROM KII COAST, MIDDLE JAPAN ${ }^{122)}$
}

\author{
Huzio UTINOMI
}

Seto Marine Biological Laboratory, Sirahama

With Plate I and 8 Text-figures

Our previous knowledge of the Japanese Alcyonaria has been derived from widely scattered references, mostly dealing with one or a few species, and from the reports of several zoological expeditions which have visited the oriental region. Among these reports are very scarce especially those recording or describing the species of the Alcyoniidae, which are mostly confined to deep-water forms, e. g. Nidalia, Anthomastus and Bathyalcyon. For the past several years I have engaged in collecting the shallow-water octocorals around the Kii coast, where the marine fauna as a whole is characterized, apart from the endemic element, by a number of tropical elements. Although the collection is by no means extensive, it nevertheless provides us with some new items of interest concerning the Japanese Alcyonarian fauna.

The present paper comprises nine species of the Alcyoniidae hitherto obtained around the Kii coast. Of these, one (Microspicularia arborea) is new to science and four ( $M$. digitulata, Sinularia gardineri, Sarcophyton elegans and Lobophytum batarum) are recorded for the first time from Japan.

\section{Nidalia rigida (PÜTTER)}

(Fig. 1)

Bellonella rigida PÜtTER, 1900, p. 448, pl. 29, fig. 1.

Eleutherobia japonica PÜtTeR, 1900, p. 449, pl. 29, figs. 2 \& 11.

Nidalia rigida KÜKenthal, 1906a, p. 33; KUKEnTHAL, 1906b, p. 29.

Not Nidalia rigida ${ }^{3}$ DeIchmann, 1936, p. 57, pl. 4, fig. 4.

1) Contributions from the Seto Marine Biological Laboratory, No. 237.

2) Supported by a grant in aid for fundamental scientific research from the Ministry of Education.

3) Deichmann's N. rigida from the Atlantic coast of North America is undoubtedly not the same as this PüTTER's rigida, but apparently related to the Atlantic species $N$. occidentalis GraY. I thus propose to rename DeIChmann's species as $N$. deichmannae nom. nov., if distinct from $N$. occidentalis.

Publ. Seto Mar. Biol. Lab., IV (1), 1954. (Article 5) 
Nom. Jap. Bô-umiitigo (nom. nov.).

The collection contains somewhat smaller eleven specimens, about $39-97 \mathrm{~mm}$ in total length. The largest figured here consists of a polyp-bearing capitulum $53 \mathrm{~mm}$ long, with a diameter of $15 \mathrm{~mm}$ at the middle and a sterile stalk, deeply shrunk and bent, about $30 \mathrm{~mm}$ long with a diameter of $10 \mathrm{~mm}$ at the base. The relative length between the capitulum and the stalk varies greatly as follows-1:1, $3: 2,5: 3,2: 1$, $5: 2,3: 1$. The base of the stalk is usually expanded, without any stolon, and attached to shell or sand particles, but rarely narrowed and roundly ended with a hint of free end in pennatulids. Probably this is due to the condition of substratum, as pointed out by KüKENTHAL (1906b, p. 30).

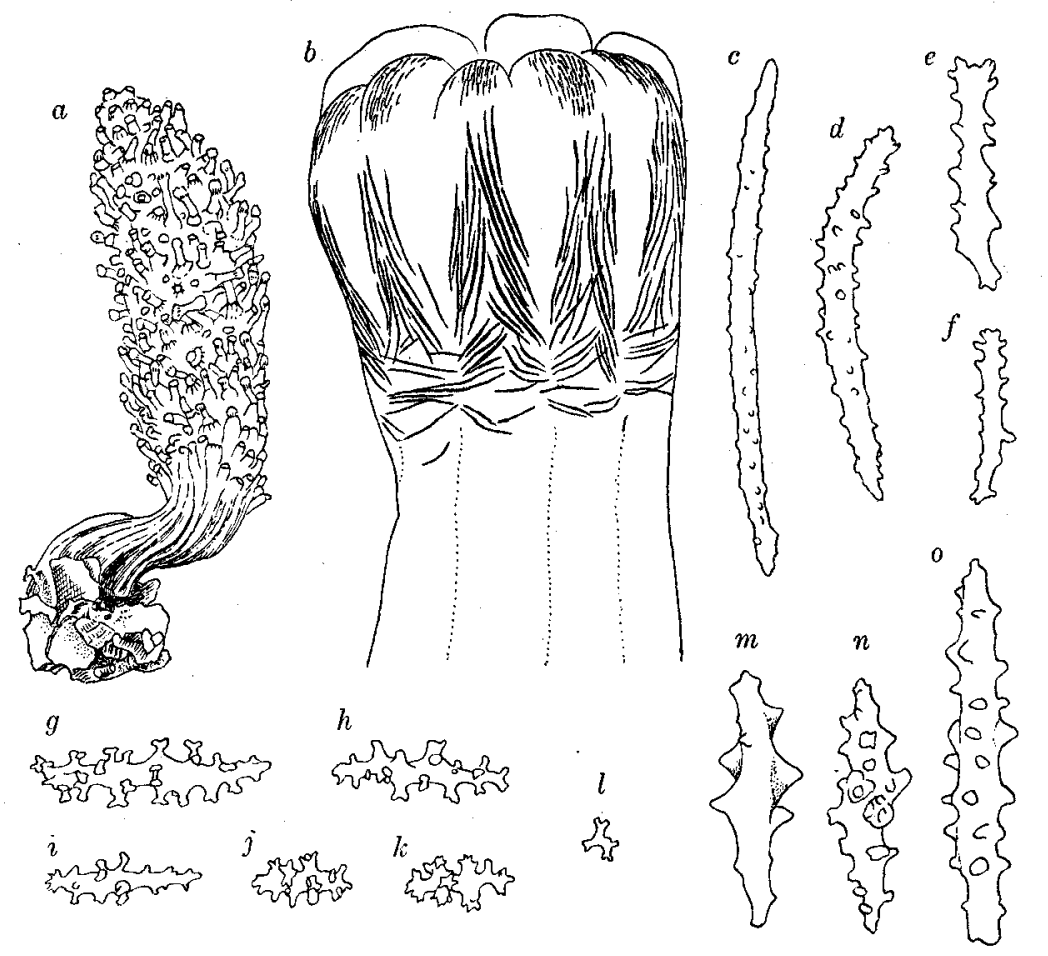

Fig. 1. Nidalia rigida (PÜTTER).

$a$, Colony ; $b$, polyp to show the arrangement of spicules; $c-d$, spicules from anthocodial crown; $e-f$, from tentacles; $g-k$, from calyx; $l$, upper view of wart of calycular spicules, magnified; $m-0$, spicules from stalk cortex.

$(a, \times 1 ; b, \times 26 ; c-k, m-0, \times 150)$

The spiculation agrees well with PÜTTER's and KükEnTHAL's descriptions and figures, but the coloration differs somewhat. Most of the polyps have their anthocodial portion completely retracted within the calyx. They attain $4 \mathrm{~mm}$ long with a diameter of $1.3 \mathrm{~mm}$ when fully expanded and their calyx is $2 \mathrm{~mm}$ wide at the base. The tentacles bear a pair of about 15 pinnules and $0.08-0.12 \mathrm{~mm}$ long toothed rodlike 
spicules. The anthocodial portion is thickly beset with 8 chevroned rows of rosy slender spindles, about $0.18-0.35 \mathrm{~mm}$ long. The neck portion is entirely devoid of spicules. The calyx rind contains smaller spindles with distinct girdles of prominent branched warts, about $0.05-0.086 \mathrm{~mm}$ long and $0.02-0.027 \mathrm{~mm}$ wide. In the rind of the stalk are found larger spindles with larger but simple warts, about $0.06-0.15 \mathrm{~mm}$ long and $0.03-0.047 \mathrm{~mm}$ wide. The canal-walls of the stalk contain similar spindles.

The ground color of the capitulum and the basal portion of calyces, as well as the anthocodial spicules is blood-red, while the main part of the stalk and the tip of calyces are dirty white.

In a largest specimen figured here, the interspace between polyps is covered with the colonies of an athecate hydroid Hydrichthella epigorgia STECHOw which occurs commonly on the gorgonian Anthoplexaura dimorpha KÜKenTHaL.

Localities. Seto, about $20-30 \mathrm{~m}$. One large colony taken with the lobster-net “ebiami ”, Utinomi coll., 1952.

Kii Strait, probably off Minosima, depth unknown. Ten colonies taken with beam trawls “utase", March 1950, R. Isibasi coll.

Hitherto known only from Japan (Nagasaki, Enosima) and west of Formosa.

\section{Nidalia dofleini KüKENTHAL}

(Fig. 2)

Nidalia dofleini Kükenthal, 1906a, p. 35 ; KükenthaL, 1906b, p. 27, text-figs. 18 \& 19, pl. 2 , figs. 8 \& 9 ; Thomson and DeAN, 1931, p. 34, pl. 5, fig. 5 \& pl. 25 , fig. 5.

Nom. Jap. Eda-umiitigo (nom. nov.).

Five small branched specimens agree well with KüKENTHAL's descriptions and figures of this species. The largest one measures $45 \mathrm{~mm}$ in height with a basal diameter of $5 \mathrm{~mm}$. The branching is two to seven times; the initial state of side branches is nothing but a prolongation of one or a few polyps grouped together. The color of the colony varies from pinkish cinnamon to red orange with the calyces generally orange. The spicules are all warty spindles, as figured here in details.

Localities. Off Minabe, $100-200 \mathrm{~m}$. Five colonies, S. SAKAGuchi coll.

Besides, I have examined also many specimens of this species, trawled off Tosa Bay which were presented to me by Dr. Kamohara of Kôchi University.

Previously recorded from Sagami Bay, $150 \mathrm{~m}$ and E. of Sumbawa Is., $69 \mathrm{~m}$ (East Indies).

\section{Alcyonium gracillimum KÜKENTHAL}

(Fig. 3) 


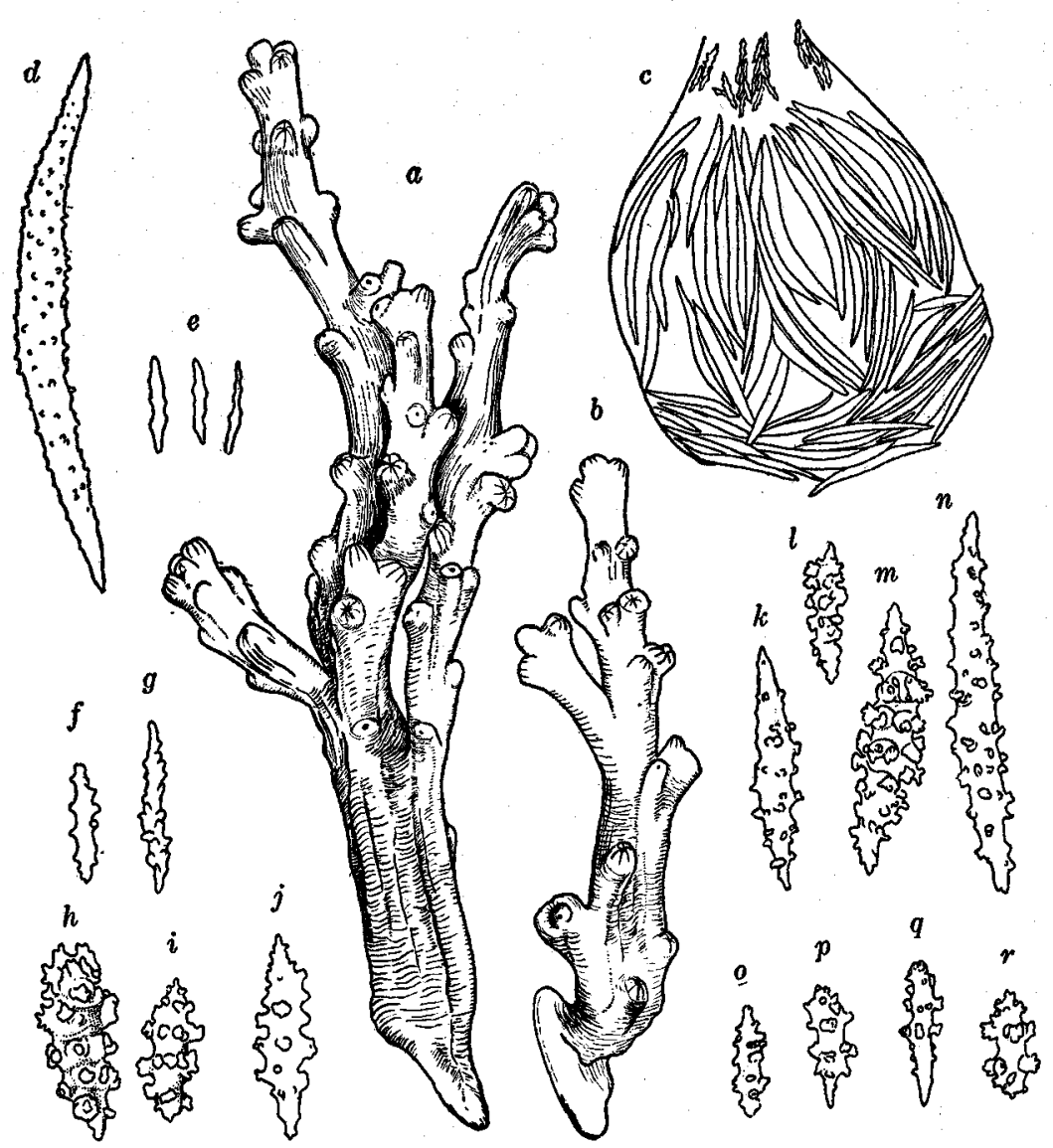

Fig. 2. Nidalia dofleini KüKenTHAL.

$a-b$, Branched colonies; $c$, retracted polyp to show the arrangement of spicules; $d$, point spicule; $e$, spicules from neck portion of polyp; $f-g$, from tentacles; $h-i$, from stalk cortex; $j$, from stalk coenenchyma; $k-n$, from inner cortical layer of polyparium; $0-\gamma$, from outer cortical layer of poly parium. $(a-b, \times 2 ; c, \times 33 ; d-r, 100)$

Alcyonium gracillimum KükenTHAL, 1906b, p. 34, text-figs. 25-27, pl. 2, fig. 13; Nutring, 1912, p. 21.

Nom. Jap. Beni-umitosaka (nom. nov.).

Numerous specimens, living and preserved, from various localities along the Kii coast, are examined. The majority of them are low branched colonies covered with irregularly lobulated masses of polyps, and attain about $10 \mathrm{~cm}$ in total height. The base membranous, often bluntly extending like stolons, and arise one or a few plump main stems.

The retracted polyps are round cones, about $1 \mathrm{~mm}$ high and wide, covered with 8 chevroned curved spindles and below these transversely arranged long spindles. 
These spicules are about $0.14-0.6 \mathrm{~mm}$ long. The stalk rind bears almost similar but longer blunt-ended spindles, mostly $0.15-0.2 \mathrm{~mm}$ long up to $0.3 \mathrm{~mm}$ long. The canalwalls are very thick and densely filled with plump spindles with large compound warts, up to $1 \mathrm{~mm}$ long.

The colonies are usually orange-colored in the living state, but when preserved in alcohol, the color fades away and turns to yellowish brown to dirty white.

Localities. Tanabe Bay, 5-30 m ; off Minabe, 100-200 m; Kii-ôsima, $6 \mathrm{~m}$.

Hitherto known only from Japan (Sagami Bay) and SW. of Sagalien.

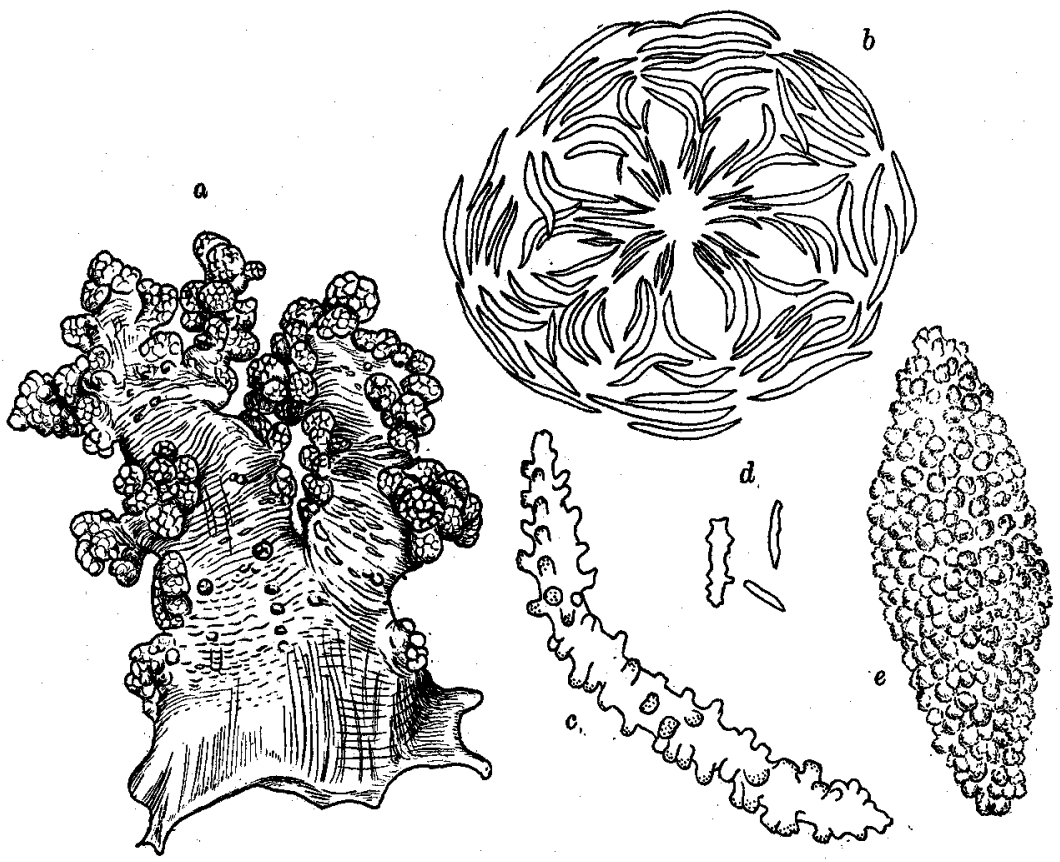

Fig. 3. Alcyonium gracillimum KüKENTHAL.

$a$, Colony $; b$, anthocodial armature, seen from above; $c$, point spicule; $d$, tentacle spicules; $e$, coenenchymal spicule.

$(a, \times 2 / 3 ; b, \times 33 ; e, \times 55 ; c-d, \times 150)$

\section{Microspicularia digitulata (KLUNZINGER)}

(Fig. 4 ; Pl. I, Figs. 2 \& 3)

Alcyonium digitulatum KLUnZINGER, 1877, p. 24, pl. 1, fig. 3; LÜtTSCHWAGER, 1922, p. 324 ; Roxas, 1933, p. 358.

Lobularia digitulata Thomson \& DeAn, 1931, p. 39 ; Tixier-Durivault, 1943, p. 441 ; TIXIERDURIVAULT, 1948, p. 153, text-figs. 147-153.

Nom. Jap. Yubi-nôtosaka (nom. nov.).

The encrusting alcyoniid commonly found at low tide around the coast of Tanabe Bay seems to be referable to this widespread species. All the specimens preserved 
in alcohol are rather small and low encrusting in form, the largest one measuring about $95 \times 45 \mathrm{~mm}$ in size of capitulum and $30 \mathrm{~mm}$ in maximum height. In younger colonies, each lobe on the capitulum is highly compressed, while in larger ones short and plump fingerlike, generally branched, attaining about $25 \mathrm{~mm}$ long and $10 \mathrm{~mm}$ wide at the base. In the living state, however, the fingerlike lobes extend up to about $50 \mathrm{~mm}$ in length.

Polyps are small, about $0.7 \mathrm{~mm}$ in diameter and densely set all over the lobes. The tentacles bear 4 or 5 broad pinnules on each side. Spicules are crowded at the ends of pinnules only or all along the aboral side of pinnules from the rachis of tentacles; these spicules are finger-biscuit-like to elongate discs, $0.03 \times 0.011 \mathrm{~mm} \sim$ $0.038 \times 0.015 \mathrm{~mm}$. Anthocodial spicules are similar in shape but a little larger, about $0.05 \times 0.02 \mathrm{~mm} \sim 0.06 \times 0.016 \mathrm{~mm}$. The spicules contained in the cortex of lobes are
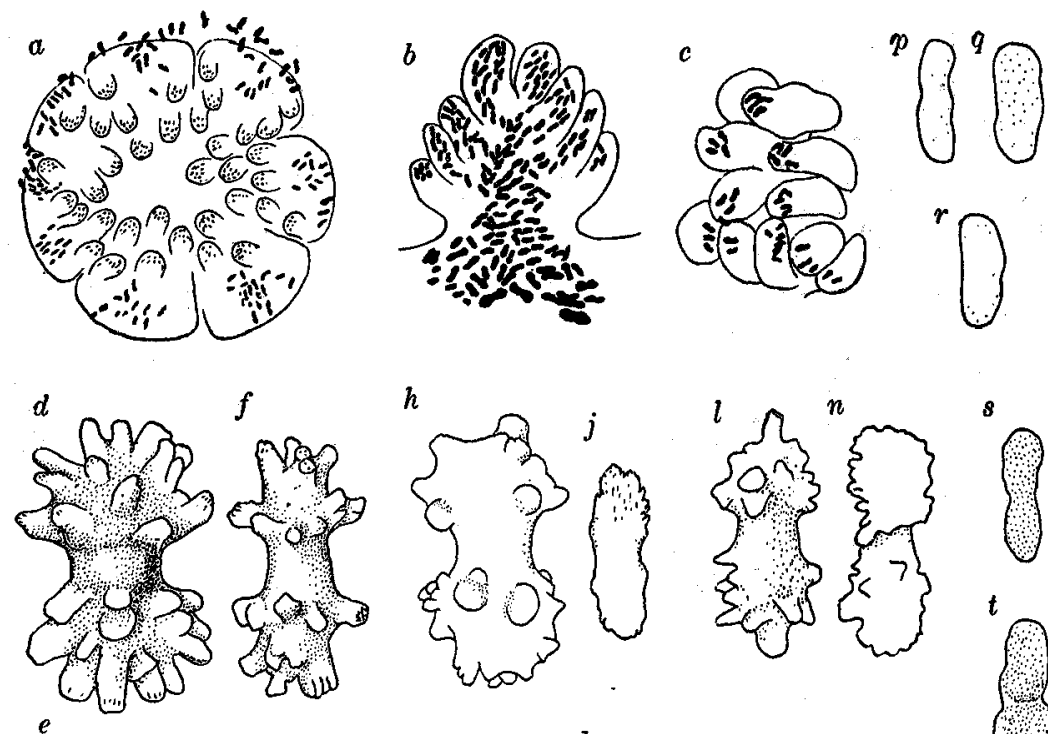

8
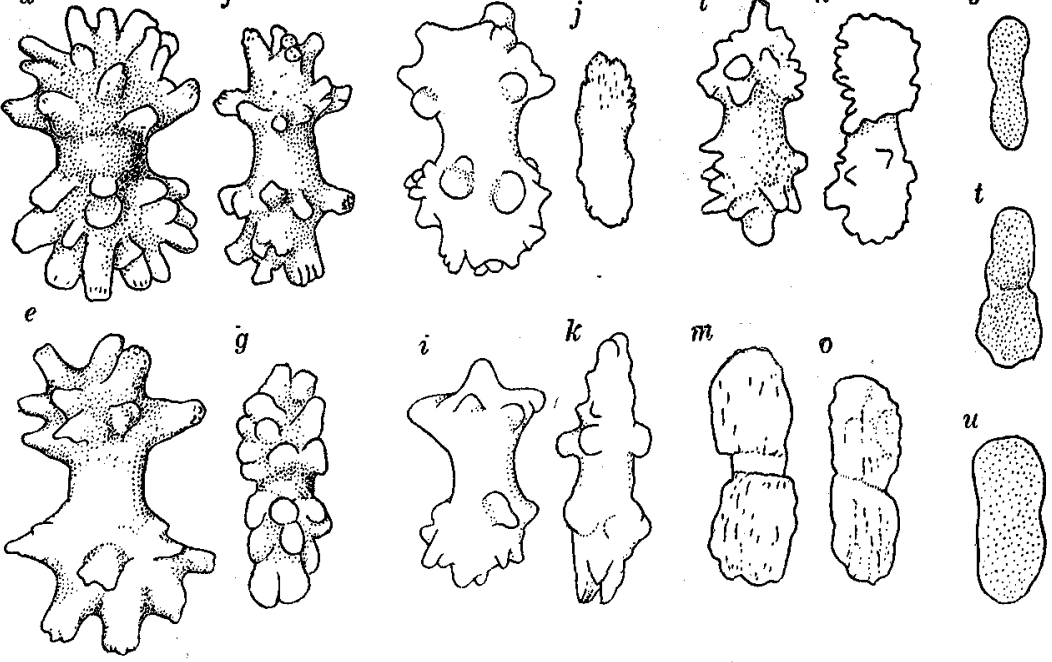

Fig. 4. Microspicularia digitulata (KLUNZINGER).

$a$, Partially retracted polyp, seen from above; $b$, tentacle bearing spicules on axis and pinnules; $c$, tentacle bearing spicules at ends of pinnules alone; $d-g$, spicules from coenenchyma of base; $h-k$, from cortex of base; $l-a$, from cortex of lobes; $p-r$, from tentacles; $s-u$, from anthocodia.

$(a, \times 55 ; b-c, \times 70 ; d-u, \times 335)$ 


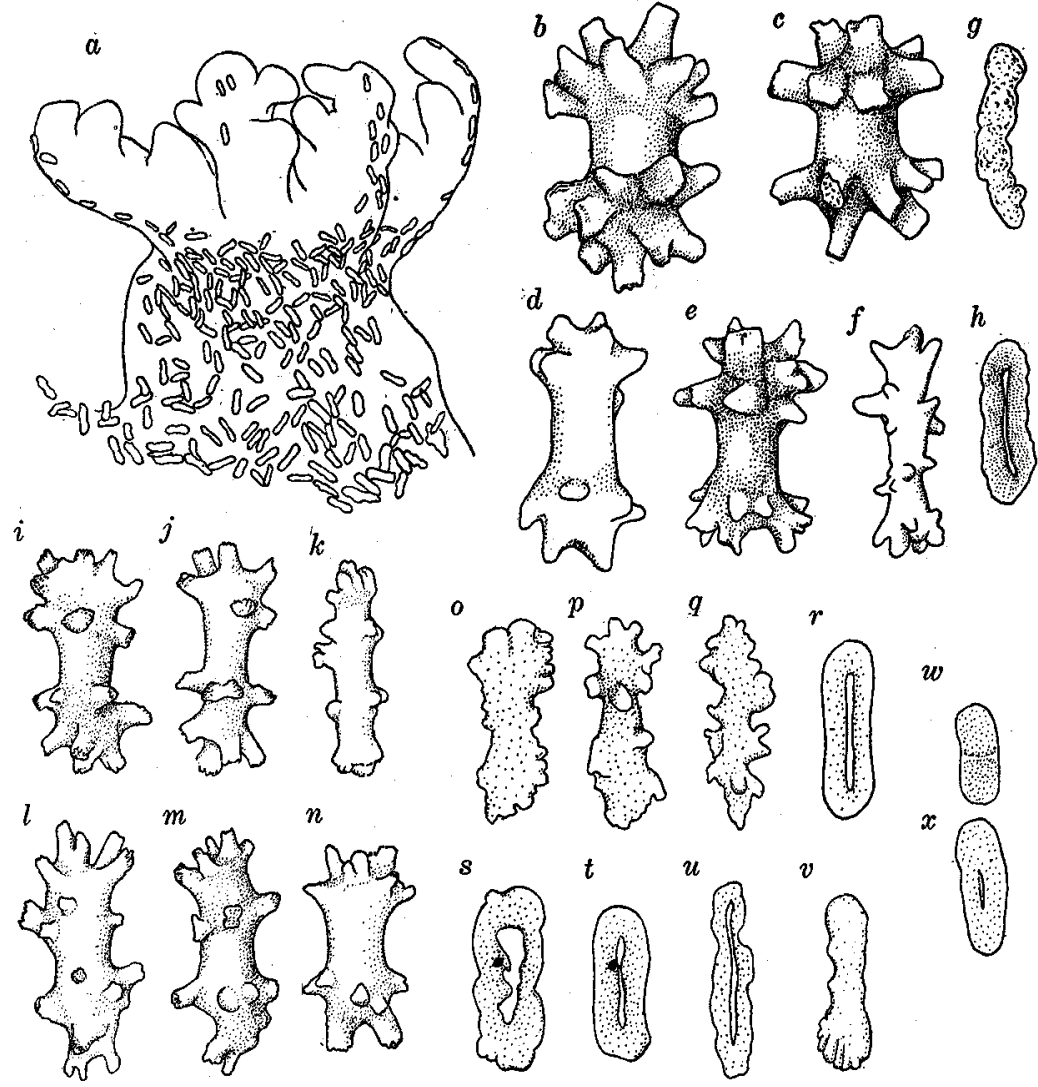

Fig. 5. Microspicularia arborea n. sp.

$a$, Polyp, seen from side; $b-h$, spicules from coenenchyma of base; $i-k$, from coenenchyma of lobes; $l-n$, from cortex of base; $a-r$, from cortex of lobes; $s-v$, from polyps ; $w-x$, from tentacles. $\quad(a, \times 55 ; b-x, \times 335)$

mostly roughened dumb-bells with or without a median constriction, about $0.03 \times$ $0.01 \mathrm{~mm}$ or thorny dumb-bells with a long waist, about $0.038 \times 0.015 \mathrm{~mm}$. Those in the cortex of the stalk are also thorny dumb-bells with a few rounded warts at ends, about $0.045 \times 0.015 \mathrm{~mm} \sim 0.07 \times 0.03 \mathrm{~mm}$. In the coenenchyma of the stalk are contained more tuberculated dumb-bells, with a median waist of variable length, $0.07 \times 0.038 \mathrm{~mm} \sim$ $0.1 \times 0.05 \mathrm{~mm}$.

Living colonies vary in color from light brown to purplish brown owing to the occurrence of zooxanthellae in endoderms. The color turns after preservation ultimately to bluish or greenish white.

Locality. Tanabe Bay, common at low tide. Probably occurs on neighboring coasts.

Previously recorded from Red Sea, Zangibar, East Indies and Philippines. 


\section{Microspicularia arborea n. sp.}

(Fig. 5; Pl. I, Fig. 1)

Nom. Jap. Eda-nôtosaka (nom. nov.).

A much branched greyish-white colony (holotype) stands $75 \mathrm{~mm}$ in height and has a maximum spread of $90 \mathrm{~mm}$. Another colony is somewhat smaller, but shows a similar appearance. From a short narrow stalk, about $25 \mathrm{~mm}$ across at the base, arise 4 main flexible, arborescent stems bearing many fingerlike branches and branchlets up to $2 \mathrm{~cm}$ long, with a diameter of $6 \mathrm{~mm}$. The main stem is not distinctly delimited from the sterile stalk, as its lower part is covered scatteredly with polyps in more or less longitudinal rows.

The polyps are about $0.5 \mathrm{~mm}$ in diameter, $0.65 \mathrm{~mm}$ in height (excluding tentacles) and number about 5 to a length of $5 \mathrm{~mm}$ on branches. As can be seen at the partially expanded condition, the anthocodia is covered irregularly with finger-biscuitlike or elongate disc-shaped tiny spicules, about $0.05 \times 0.01 \mathrm{~mm} \sim 0.06 \times 0.018 \mathrm{~mm}$, and the tentacles, about $0.5 \mathrm{~mm}$ long, with 3 broad pinnules on each side, bear only a few smaller spicules $(0.04 \times 0.01 \mathrm{~mm})$ on the aboral side of rachis; no spicules on pinnules. In the cortex of lobes or branches are rough-edged elongate discs or cylinders with or without a median constriction, about $0.05 \times 0.01 \mathrm{~mm} \sim 0.065 \times 0.02 \mathrm{~mm}$. In the canal-walls of lobes and also the cortex of sterile stalk are dumb-bells with a distinct median waist and two whorls of a few blunt-tipped warts at both ends, $0.07 \times 0.025 \mathrm{~mm} \sim 0.09 \times 0.03 \mathrm{~mm}$. The canal-walls of sterile stalk contain various forms of spicules, such as :

Capstans with a cluster of blunt-ended warts at heads, about $0.07 \times 0.03 \mathrm{~mm} \sim$ $0.09 \times 0.05 \mathrm{~mm}$.

Tuberculate cylinders, about $0.08 \times 0.025 \mathrm{~mm}$.

Elongate discs with or without a central thin zone, about $0.06 \times 0.018 \mathrm{~mm}$.

Locality. Seto, Tanabe Bay. Two colonies taken with lobster-nets.

Remarks. This is most related to M. letourneuxi (TIx.-Dur.) M. elegantissima (MAY) in arborescent form of growth, but can be easily separated from both in the shape and spiculation of tentacles and also in the peculiar shape of coenenchymal and cortical spicules.

\section{Sinularia gardineri (PRATT)}

(Fig. 6)

Sclerophytum Gardinèri PRATT, 1903, p. 527, pl. 31, fig. 28 ; PRATT, 1905, p. 255.

Sinularia gardineri THOMSON \& DEAN, 1931, p. 52, pl. 13, fig. 1 \& pl. 22, fig. 4 \& pl. 23, fig. 8; Macfadyen, 1936, p. 34, text-figs. 3-4, pl. 5, fig. 2; Tixier-Durivault, 1945, p. 245 .

Nom. Jap. Siba-katatosaka (nom. nov.). 
A flat, low-growing colony, with a spread of $5 \times 4 \mathrm{~cm}$ and a height of $2-2.5 \mathrm{~cm}$, closely resembles MACFADYEN's photo of this species in her Great Barrier Reef report (1936, pl. V, fig. 2) in the form of growth, although the shape of cortical spicules is not exactly identical. Upon the flat capitulum delimited from a short sterile stalk around the edge, arise a number of short, scarcely branched lobes; the average length of main lobes is about $10 \mathrm{~mm}$ in the centre and $5 \mathrm{~mm}$ near the edge. The color is creamy white, and the texture is hard and brittle. The autozooids are fully retracted and very inconspicuous. There is no siphonozooid.

Cortical spicules in the stalk and lobes are similar in shape and size. They are typical clubs, about $0.17 \times 0.07 \mathrm{~mm} \sim 0.22 \times 0.1 \mathrm{~mm}$, which are short, with 4 large compound warts around the head and a few smaller ones around the shaft; the central one at the tip of head as shown in MACFADYEN's specimens is not encountered. Coenenchymal spicules are all plump spindles with large compound warts, measuring
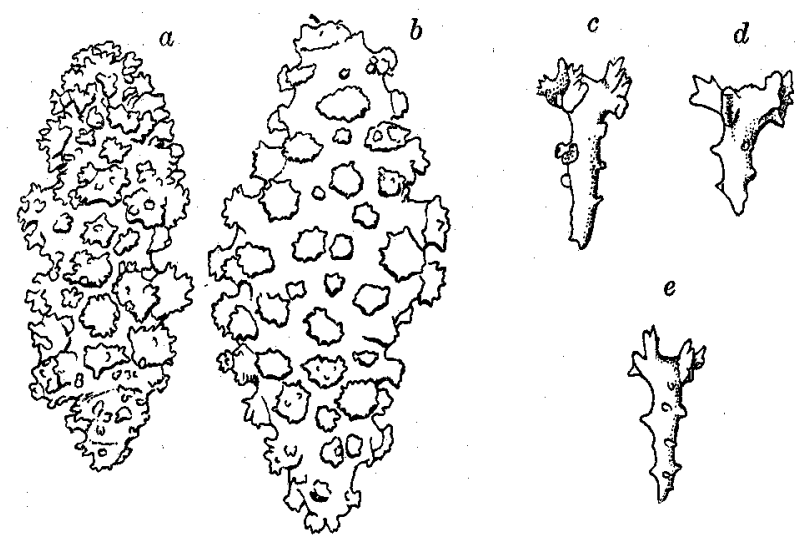

Fig. 6. Sinularia gardineri (PRATT). $a-b$, Coenenchymal spicules; $c-e$, cortical spicules.

$($ All $\times 100)$

$0.5 \times 0.3 \mathrm{~mm}, 0.8 \times 0.3 \mathrm{~mm}, 1.5 \times 0.47 \mathrm{~mm}$ and $2.0 \times 0.5 \mathrm{~mm}$.

Locality. Off Minabe, dredged from a depth of $100-200 \mathrm{~m}$. One specimen, April 1938, S. Sakaguchi coll.

Previously recorded from Red Sea, Indian Ocean (Maldive Is., Gulf of Manaar, S. of Malha, Seychelles Is.), East Indies, Great Barrier Reef (Low Isles).

Remarks. This is a shallow water form principally living in the Indo-Pacific coral reefs. Therefore, the finding of this species in deeper waters of Japan is worthy of note.

\section{Sarcophyton acutangulum (MARENZELLER)}

Nom. Jap. Umitake.

The occurrence of this species in the Kii coast was reported only briefly (UTINOMI, 
1953, p. 155). An example from Kii-ôsima is $25 \mathrm{~mm}$ high, with the capitulum about $40 \times 55 \mathrm{~mm}$ in spread. Another young colony from Seto is a thick, mushroom-shaped type of a dark grey color.

Localities. Kii-ôsima, $5 \mathrm{~m}$; Seto, Tanabe Bay, $15 \mathrm{~m}$.

\section{Sarcophyton elegans MOSER}

(Fig. 7)

Sarcophyton elegans Moser, 1919, p. 252, text-fig. 11, pl. 5, fig. 9 ; RoxAS, 1933, p. 380, pl. 1 , fig. 9; MACFADYEN, 1936, p. 42.

Sarcophytum convolutum THOMSON \& DEAN, 1931, p. 63, pl. 11, fig. 7 \& pl. 23 , fig. 1. Sarcophytum elegans TIXIER-DURIVAULT, 1946, p. 86.

Nom. Jap. Hira-umitake (nom. nov.).

A large colony recently dredged from Tanabe Bay can be referred to this species. It shows the thin-margined, irregularly folded disc distinctly delimited from the cup-shaped low stalk. The marginal folds are broader than high and the centre of the disc is not much lower than the edge. It stands about $6 \mathrm{~cm}$ in height; the disc has a maximum diameter of $18 \mathrm{~cm}$ and the stalk a basal diameter of about

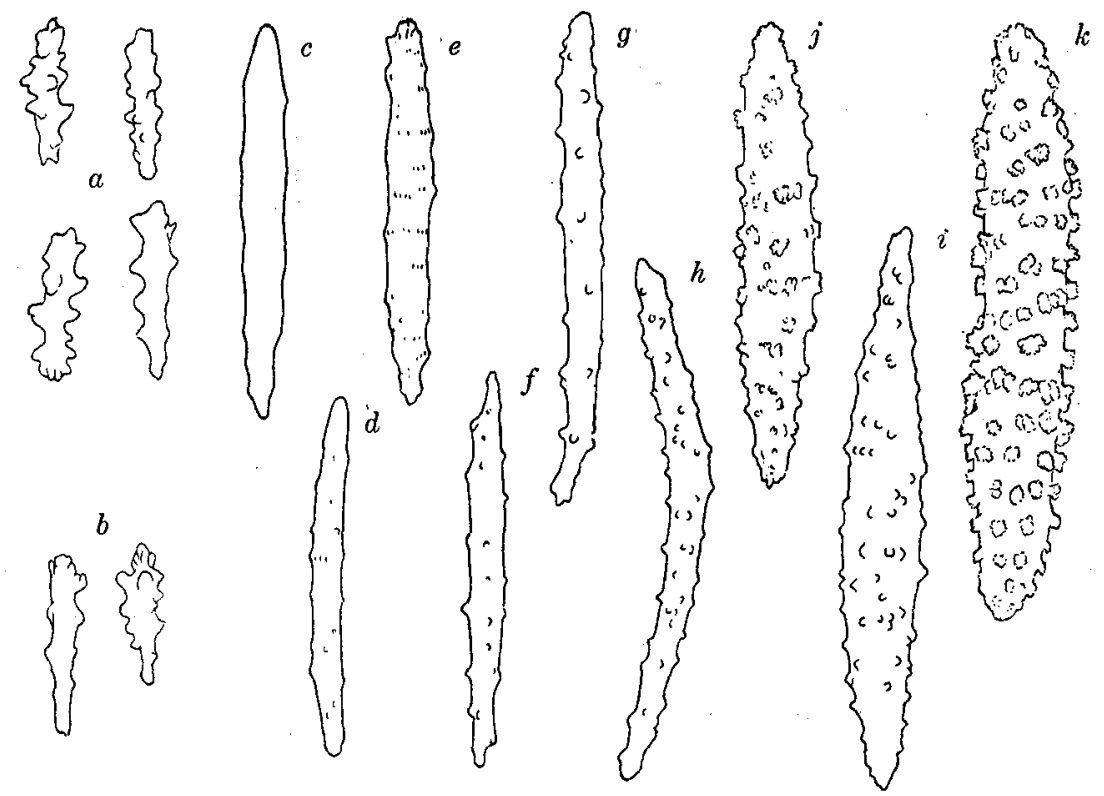

Fig. 7. Sarcophyton elegans Moser.

$a$, Warty rods of stalk cortex; $b$, pseudo-clubs of disc cortex; $c-g$, slender spindles of disc interior covered with minute warts, sometimes zoned or often unwarted as in $c ; h-i$, the same of stalk interior covered with simple warts : $j-k$, larger spindles of stalk interior covered with more or less compound warts.

$(a-h, \times 150 ; i-k, \times 100)$ 
$5-6 \mathrm{~cm}$. When living, the disc is wholly purplish brown and the stalk ochre-yellow with numerous longitudinal striation of purple color which owes to the abundance of zooxanthellae contained within the endoderm.

The majority of the autozooids are fully expanded up to $5 \mathrm{~mm}$ in length. They are $2-3 \mathrm{~mm}$ apart at the edge of the disc and $5-8 \mathrm{~mm}$ apart in the centre. There are on the average 7-10 siphonozooids between two autozooids. The tentacles of autozooids have 8 pairs of short pinnules and bear densely packed numerous, simple or scarcely warted, rodlike spicules. Similar spicules are arranged transversely on the stalk of polyps, though not so thickly set as in the head.

The spiculation agrees closely with THOMSON \& DEAN's description of S. convolutum which is synonymous with S. elegans. The spicules consist of three forms. Cortical spicules in the stalk as well as the disc are small warty rods, sometimes clublike in form, being broader and more warty at one end; they are about $0.08 \times 0.023 \mathrm{~mm}$, $0.09 \times 0.03 \mathrm{~mm}$ and $0.1 \times 0.023 \mathrm{~mm}$. In the disc interior are slender and much longer spindles covered with relatively few tiny warts which are often zoned or entirely lacking; they are about $0.3 \times 0.02 \mathrm{~mm}, 0.35 \times 0.028 \mathrm{~mm}$ and $0.4 \times 0.02 \mathrm{~mm}$. Towards the base the coenenchymal spicules tend to much larger and to bear stronger, simple or compound, warts, up to $0.8 \times 0.12 \mathrm{~mm}$.

Locality. Entrance of Tanabe Bay, $30 \mathrm{~m}$. One specimen, July 24, 1954.

Previously recorded from East Indies, Philippines, Great Barrier Reef and Madagascar.

\section{Lobophytum batarum MOSER}

(Fig. 8; Pl. I, Fig. 4)

Lobophytum batarum MOSER, 1919, p. 268, text-fig. 14, pl. 6, fig. 13; ROXAS, 1933, p. 362.

Nom. Jap. Hai-unetake (nom. nov.).

Five large, complete or incomplete, dry specimens are contained in the collection. The largest one among complete specimens measures $20 \times 14 \mathrm{~cm}$ in spread of the disc. The stalk is much constricted and slightly widened apically, so that its accurate height cannot be measured, but approximately $3-5 \mathrm{~cm}$ long at the constricted state. The texture of the colony is very hard, and the color is brownish white, but darker in alcohol.

The disc is flattened, with a number of radially arranged, but not reaching the middle, high folds of rather even thickness $(5-10 \mathrm{~mm}$ wide); the folds are often divided into high or low lobes at the tip up to $3 \mathrm{~cm}$ high, but not prolonged into digitiform processes. On these the autozooids are closely set, and between two autozooids lies only one row of small siphonozooids. Cortical spicules are simple spindles or somewhat club-like with warty heads, mostly about $0.14 \times 0.04 \mathrm{~mm}$ to $0.25 \times 0.05 \mathrm{~mm}$. In the stalk interior are all warty spindles on the average 0.25 to 

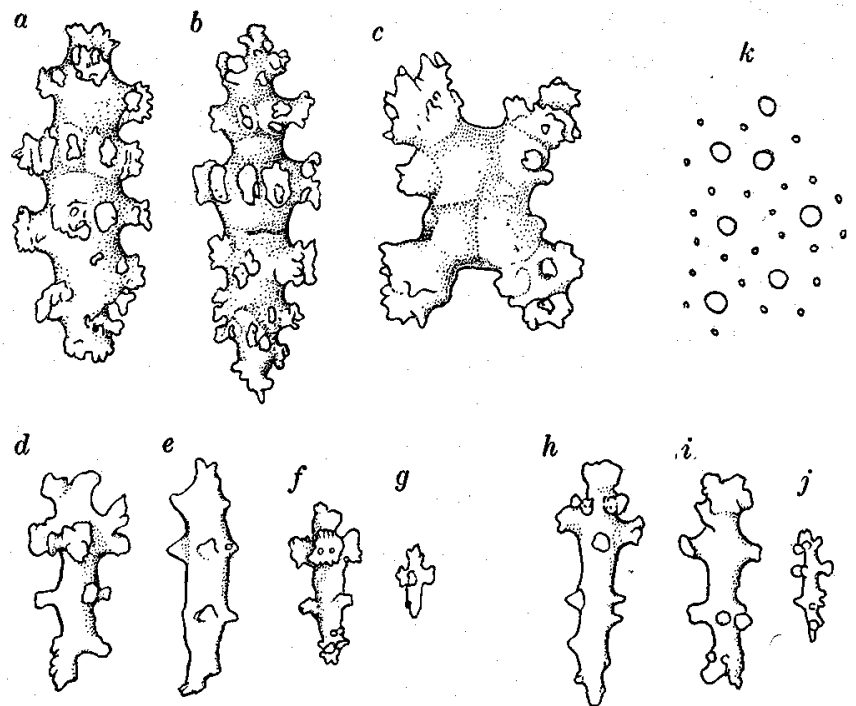

Fig. 8. Lobophytum batarum MOSER.

$a-c$, Spicules from coenenchyma of base; $d-g$, from cortex of base; $h-j$, from coenenchyma of capitular disc; $k$, part of disc, showing the arrangement of auto- and siphonozooids.

$(a-j, \times 150)$

$0.3 \mathrm{~mm}$ long and 0.07 to $0.085 \mathrm{~mm}$ wide, covered with heavy warts arranged in 4 to 6 distinct whorls; crosses may also be found.

Three of the colonies harbour on the capitulum a number of the epizoic barnacle apparently like Acasta fenestrata DARwin which occurs usually on Discodermia-like lithistid sponges.

Locality. Kii-ôsima. Five dry specimens, July 17, 1939, S. SAKaguchi coll.

Hitherto known only from Philippines.

\section{LITERATURE}

Deichmann, E. 1936. The Alcyonaria of the western part of the Atlantic Ocean. Mem. Mus. Comp. Zool. Harvard, vol. 53, pp. 1-317, 37 pls.

KLUnzinger, C. B. 1877. Korallthiere des Rothen Meeres. Erster Theil: Die Alcyonarien und Malacodermen. Berlin, vii +94 pp., 7 pls.

KüKenthal, W. 1906a. Alcyonaria. Wiss. Ergebn. Deut. Tiefsee-Exped. auf dem Dampfer "Valdivia ", XIII, 1. Jena, 111 pp., 12 pls.

- 1906b. Japanische Alcyonaceen. Abhand1. K. Bayer. Akad. Wiss. II Kl. Suppl. Bd. I, Abt., pp. 9-86, 5 pls.

LÜtTschwager, H. 1922. Alcyonarien von den Philippinen. I. Die Gattung Alcyonium Linnaeus. Philip. Jour. Sci., vol. 20 , pp. 519-540, 1 pl.

MacFadyen, L. M. I. 1936. Alcyonaria (Stolonifera, Alcyonacea, Telestacea and Gorgonacea). Great Barr. Reef Exped., Sci. Rep., vol. 5, no. 2, pp. 19-71, pls. 1-5.

Moser, J. 1919. Beiträge zu einer Revision der Alcyonarien. I. Die Gattungen Sarcophyton Lesson und Lobophytum Marenzeller. Mitt. Zool. Mus. Berlin, Bd. 9, pp. 219-293, pls. 5-6. 
Nutting, C. C. 1912. Descriptions on the Alcyonaria collected by the U. S. Fisheries Steamer "Albatross," mainly in Japanese waters, during 1906. Proc. U. S. Nat. Mus., vol. 43, no. 1923, pp. 1-104, pls. 1-21.

Pratt, E. M. 1903. Alcyonaria. Fauna and Geogr. of Maldive and Laccadive Archipelagoes, vol. 2 , pp. $503-539$, pls. $28-31$.

1905. Report on some Alcyoniidae collected by Prof. Herdman, at Ceylon in 1902.

Rep. Pearl Oyster Fisheries, Gulf of Manaar, Suppl. Rep., no. 19, pp. 247-268, pls. 1-3.

PƯtter, A. 1900. Alcyonaceen des Breslauer Museums. Zool. Jahrb. Abt. Syst., Bd. 13, pp. 443-462, pls. $29-30$.

RoxAs, H. A. 1933. Philippine Alcyonaria, II. The families Alcyoniidae and Nephthyidae. Philip. Jour. Sci., vol. 50, pp. 345-470, pls. 1-5.

Thomson, J. A. \& DeAn, L. M. I. 1931. The Alcyonacea of the Siboga Expedition, with an appendam to the Gorgonacea. Siboga-Expeditie, mon. 13d, livr. 115, 227 pp., 28 pls.

Tixier-Durivault, A. 1943. Les Alcyonaires du Muséum: I. Famille des Alcyoniidae. 1. Genre Lobularia. Bull. Mus. Nat. Hist. Nat. Paris, 2 sér., t. 15, no. 6, pp. 437-443.

1945. Les Alcyonaires du Muséum: I. Famille des Alcyoniidae 2. Genre Sinularia (suite). Ibid., t. 17 , no. 3 , pp. 243-250.

1946. Les Alcyonaires du Muséum: I. Famille des Alcyoniidae 3. Genre Sarcophytum. Ibid., t. 18 , no. 1 , pp. $80-86$.

1948. Révision de la famille des Alcyoniidae. I. Le genre Lobularia Ehrbg. (nec

Lamarck). Mém. Mus. Nat. Hist. Nat. Paris, N. S., t. 23, fasc. 1, pp. 1-256.

UTinomI, H. 1953. Invertebrate fauna of the intertidal zone of the Tokara Islands. VI. Alcyonaria. Publ. Seto Mar. Biol. Lab., vol. 3, no. 2, pp. 149-160, pl. 8.

\section{EXPLANATION OF PLATE I}

Fig. 1. Microspicularia arborea n. sp. (Holotype) $\times 2 / 3$.

Fig. 2. Microspicularia digitulata. (KLUnZINGER), polyps retracted. $\quad \times 1 / 2$.

Fig. 3. Microspicularia digitulata (KLUnzINGER), polyps partially expanded.

$\times 1 / 2$.

Fig. 4. Lobophytum batarum, MOSER. 
Publ. Seto Mar. Biol. Lab., IV, 1 (1954)

Plate I

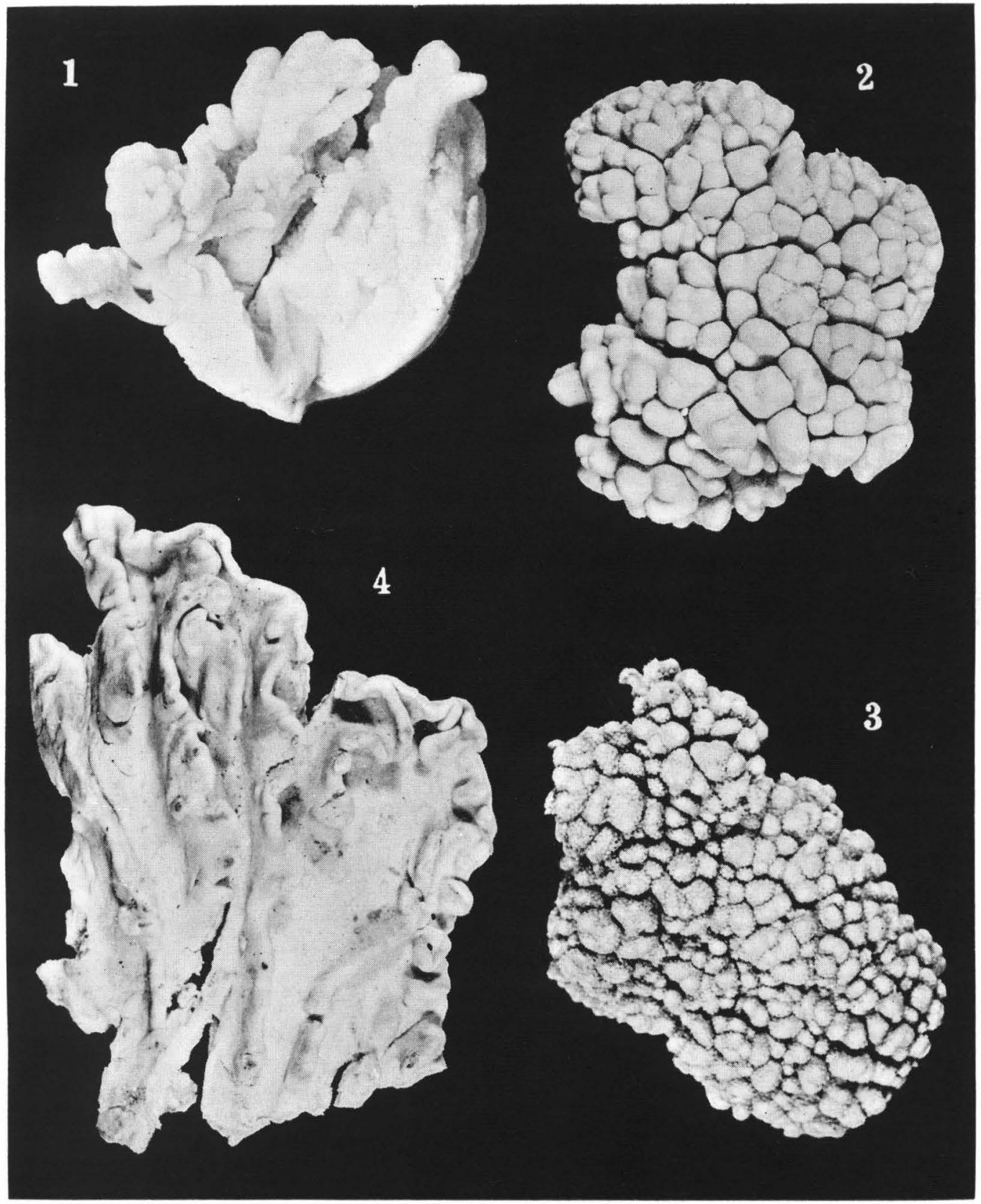

H. Utinomi : Some Alcyonitd Octocorals from Kil Coast. 